\title{
Raízes antropofágicas: labirintos e paradoxos na constituição formativa do modernismo brasileiro. ${ }^{1}$ \\ Fenômenos Antropofágicos ${ }^{2}$
}

Marta Lucia Pereira Martins Lindote ${ }^{3}$, Francine Regis Goudel ${ }^{4}$, Muriel Bombana Garcez ${ }^{5}$.

\section{Resumo}

O enfoque do artigo é dado principalmente aos fenômenos Antropofágicos, relacionando concomitantemente a Antropofagia ritual Tupinambá do Brasil Colônia à Antropofagia da Semana de Arte Moderna, abordando desde a colonização, a inserção da arte no Brasil, bem como a inserção do Brasil na Arte, passando pelo primeiro modernismo paulistano de 22 , que garantiu ao país, uma arte de caráter nacionalista, incluindo esse reflexo no presente contexto da arte no país.

\section{Palavras-chave:}

Raízes do Brasil, Antropofagia Brasileira, Modernismo Brasileiro, Semana de Arte Moderna.

O modernismo brasileiro que se instaura a partir da Semana de Arte Moderna em 1922 é um tópico cultural com relação ao passado colonial e ao futuro da globalização. Neste contexto ainda prolifera um modelo de irreverência que sustenta um regime ético e estético como modo estratégico de inserção cultural dentro e fora do país.

\footnotetext{
${ }^{\mathrm{T}}$ Projeto de Pesquisa DAP / CEART / UDESC.

${ }^{2}$ Artigo de Pesquisa produzido por Muriel Bombana Garcez.

${ }^{3}$ Orientadora, Professora do Departamento de Artes Plásticas - Centro de Artes da Universidade do Estado de Santa Catarina - UDESC - Av. Madre Benvenutta, 1907. Itacorubi - CEP 88.035-001 Florianópolis - SC.

${ }^{4}$ Acadêmica do curso de Artes Plásticas com habilitação em Licenciatura - DAP / UDESC, bolsista de iniciação científica do PROBIC / CNPq.

${ }^{5}$ Acadêmica do curso de Artes Plásticas com habilitação em Bacharelado - DAP / UDESC, bolsista de iniciação científica do PROBIC / CNPq.
} 
A constituição formativa do modernismo brasileiro além de resgatar um vínculo com o passado colonial e buscar uma forma vanguardista, ao formular um projeto de construção de identidade brasileira, cria a problemática da Antropofagia cultural no conceito oriundo das idéias manifestadas pelo poeta e ensaísta Oswald de Andrade, desenvolvidas nas décadas de 20 e 30. Tal conceito auxilia no entendimento de um momento cultural onde os artistas e intelectuais brasileiros estão focados em dois problemas: por um lado, uma apreensão das formas de ruptura com a tradição acadêmica proveniente das vanguardas européias instauradas em nosso meio no início do século XX, com o propósito radical de repensar o problema da representação e do caráter ilusionístico das artes plásticas; e por outro lado, a antropofagia cultural volta-se para uma apreensão da cultura popular do nosso próprio país utilizando-a como temática, o que se encontra estritamente relacionado ao projeto estético de uma arte à brasileira, refletida ainda no presente contexto da arte nacional e internacionalmente.

A partir dos anos 20 houve uma vigorosa corrente de renovação nas artes visuais, tanto no Brasil como na América Latina, essa corrente teve sua origem no Modernismo Europeu, devido ao fato de que quase todos os artistas latino-americanos que abraçaram o modernismo o fizeram no estrangeiro, onde ocorreram radicais transformações das artes visuais, durante as primeiras décadas do século $\mathrm{XX}$, sob influência dos movimentos do fovismo, expressionismo, cubismo, dadaísmo, purismo e construtivismo.

Contudo, o Brasil, bem como a América Latina, estava à procura de uma caracterização cultural, motivo pelo qual, a partir da percepção das diferenças entre Arte Brasileira, e ou Arte Latino Americana em contraposição a Arte Européia, inicia-se a busca a uma Arte com especificidades. “[...] Os artistas que voltavam para a América Latina, depois de uma temporada [...] no estrangeiro, passaram a criar de um modo diferente, valendose de formas do modernismo que eram especificamente americanas.”(ADES, 1997, p125)

Nas obras desses artistas, o mais freqüente era ver a tradição sendo reavaliada, bem como o período colonial e a cultura europeizada do século XX comumente sendo rejeitados, em troca de uma tradição cultural indígena de raízes mais fortes. "[...] $\mathrm{O}$ nacionalismo por oposição ao internacionalismo e o regional como idéia contrária àquilo que é central e cosmopolita [...]” (ADES, 1997, p.126) 
Para os modernistas a iniciação no modernismo envolvia, antes de tudo, uma completa ruptura com o seu passado e a sua formação artística acadêmica. Assim, romperam com os dogmas herdados das academias Européias e utilizaram-se das técnicas e abordagens pictóricas estrangeiras aliadas as peculiaridades de sua nacionalidade para modernizar suas obras à fim de atender a demanda de um mercado globalizado. Os artistas modernistas latino-americanos que já tinham entrado em contato com movimentos mais radicais das vanguardas na Europa, proporcionavam em suas obras uma linguagem visual sentida como mais capaz de exprimir as mudanças causadas pela rápida modernização e pela industrialização do mundo.

Estes artistas visionários buscavam uma identidade cultural e artística específica. Exibindo características particulares da nacionalidade latino-americana, através das obras principalmente literárias e plásticas, por meio de manifestos e textos publicados em revistas, eventos, telas inusitadas, pinturas murais e arte pública, política e social, valendo-se da identificação de uma nação, bem como da consciência de uma "arte para todos", uma "arte para o povo", "uma arte revolucionária", inspirada na notória vontade reacionária dos modernistas de passar a idéia aos representantes da arte no momento, utilizando de certo caráter pedagógico correlativo à intenção de difundir para o público espectador.

Desse modo, o Modernismo no Brasil estabeleceu forte relação entre arte radical e política revolucionária, vista a reação de escritores, artistas e intelectuais, marcada, sobretudo, pelos movimentos e manifestações à cerca da Semana de Arte Moderna realizada nos dias 13, 15 e 17 de fevereiro de 1922, no Teatro Municipal de São Paulo.

Já nos primórdios dos anos 20, Oswald de Andrade, antecipava os preparativos à celebração da Semana de 22 na publicação do Jornal do Comércio, onde anunciava: "Cuidado, senhores da camelote (reacionários), a verdadeira cultura e a verdadeira arte vencem sempre. Um puglio pequeno, mas forte, prepara-se para fazer valer o nosso centenário". (ALAMBERT, 1992)

Então, na Semana de Arte Moderna, no interior do teatro, foram apresentados concertos e conferências, enquanto no saguão foram montadas exposições de artistas plásticos, como os arquitetos Antonio Moya e George Prsyrembel, os escultores Vítor Brecheret e W. Haerberg e os desenhistas e pintores Anita Malfatti, Di Cavalcanti, John Graz, Martins Ribeiro, Zina Aita, João Fernando de Almeida Prado, Ignácio da Costa Ferreira, 
Vicente do Rego Monteiro e Di Cavalcanti [o idealizador da Semana e autor do desenho que ilustra a capa do catálogo].

Os "modernistas" brasileiros formavam um grupo específico cuja primeira manifestação pública foi a Semana de Arte Moderna de 1922 em São Paulo, da qual constaram exposições, recitais de poesia, concertos e conferências. Graça Aranha falou sobre o papel primordial da música e das artes visuais: "a música de Villa-Lobos, a escultura de Brecheret, a pintura de Di Cavalcanti, Anita Malfati, Vicente do Rego Monteiro, Zita Aita", bem como a "audácia dos jovens poetas..." (ADES, 1997, p. 132)

A semana de 22, Semana de Arte Moderna, foi um grande marco para a Arte do Brasil, evento caracterizador de uma nova concepção do fazer e compreender a obra de arte, caracterizador também das nossas raízes, onde fez-se alusão a Antropofagia Brasileira, decretando a redução imediata de todas as influências externas a modelos nacionais.

A nova arte, moderna e antropofágica, aparece inicialmente através da atividade crítica e literária de Oswald de Andrade, Menotti del Picchia, Mário de Andrade e alguns outros artistas, que, se conscientizando do tempo em que vivem, não deixavam de transmitir um sentimento de ruptura e animação em suas fragmentadas afirmações do mundo moderno.

Oswald de Andrade alerta para a valorização das raízes nacionais, que devem ser o ponto de partida para os artistas brasileiros, escreve:

O Manifesto da Poesia Pau-Brasil, usando a expressão "a selva e a escola", abordava, de maneira nova, o Brasil com sua cultura mulata e sua atmosfera tropical contrastando com a indústria moderna. Isso representava uma extraordinária mudança de consciência nos poetas e artistas ricos, bem-educados e altamente europeizados que constituíram o grupo de modernistas - uma mudança não para uma versão qualquer do nacionalismo, mas num sentido que tinha a ver com a forma de colonização. ( ADES, 1997, pp. 132-133)

Assim, cria movimentos e escreve para os jornais expondo suas idéias à renovadores de grupos de artistas que começam a se unir em torno de uma nova proposta estética.

Em 1928, Oswalde Andrade publica na Revista Antropofagia, o Manifesto Antropofágico, que propunha basicamente a devoração da cultura e das técnicas importadas e sua reelaboração com autonomia, transformando o produto importado em exportável.

Só a antropofagia nos une. [...] Única lei do mundo. [...] Contra todos os importadores de consciência enlatada. [...] E as inquisições exteriores. [...] Contra o mundo reversível e as idéias objetivadas. [...] E o esquecimento das conquistas interiores. [...] Já tínhamos o comunismo. [...] Tínhamos a relação e a distribuição dos bens físicos, dos bens morais, dos bens dignários. E sabíamos transpor o mistério e a morte [...] Mas não foram cruzados que vieram. Foram fugitivos de uma civilização que estamos 
comendo, porque somos fortes e vingativos como o Jabuti. [...] Antropofagia. Absorção do inimigo sacro. Para transformá-lo em totem. [...] antropofagia carnal, que traz em si o mais alto sentido da vida e evita todos os [...] males catequistas. [...] Peste dos chamados povos cultos e cristianizados, é contra ela que estamos agindo. Antropófagos. (ANDRADE, 1928)

A idéia do manifesto surgiu quando Tarsila do Amaral, para presentear o então marido Oswald de Andrade, deu-lhe como presente de aniversário a tela Abaporu, cujo título foi encontrado em um dicionário de tupi-guarani, [aba = homem; poru = que come]. Assim, o nome do manifesto recuperava a crença indígena de que os índios antropófagos comiam o inimigo, supondo que assim estavam assimilando suas qualidades.

Sabe-se que esse ritual faz parte da idéia de apropriação do outro; um "comer" o inimigo que se recusa para dele abastar-se, um devorar o outro para assimilar suas qualidades. Nesse sentido, os modernistas foram vorazes na identificação e disseminação da cultura brasileira, motivo pelo qual, citam em seus manifestos vanguardistas a força do fenômeno de assimilação e recusa, no sentido de "engolir", "digerir" e recriar, e não no sentido de absorver, aceitar e reproduzir o que vem de "fora", o estrangeiro, o "inimigo". Era essa a idéia que os modernistas esforçaram-se para embutir na caracterização da identidade do país; apresentando uma inusitada maneira do fazer artístico, uma nova concepção capaz de simultaneamente assimilar e recusar, reinventar o que vem de "fora" de uma maneira transcendente e original, originalidade esta encontrada nos vestígios do ritual indígena antropófago.

Desse modo, as origens da Antropofagia Brasileira, são provenientes do ritual indígena antropófago, que encontra-se ilustrado nas gravuras e trechos do livro Viagem ao Brasil, escrito pelo artilheiro alemão Hans Staden no século XVI. O livro consta entre as primeiras narrativas de testemunho dos viajantes europeus ao Novo Mundo, nele o autor relata os primeiros registros de viagens escritos sobre o Brasil do período colonial, e conta dentre outras aventuras, a sua detenção de nove meses entre os Tupinambás onde viveu a experiência de ser ameaçado constantemente pela possibilidade de vir a ser objeto de antropofagia ritual.

"Tudo isto eu vi e presenciei" - declara o autor em seus escritos. Partindo da premissa, constituída a partir dos relatos de Staden pode-se afirmar, que o ritual antropófago, consiste no ritual de devoração do inimigo regado á cauim, uma bebida embriagante feita a partir das raízes da mandioca, cujo preparo é parte essencial do cerimonial. Vale 
descrever conforme o capítulo XV do livro, Como fabricam as bebidas com que se embriagam e como celebram essas bebedeiras.

As mulheres é que fazem [...] as bebidas. Tomam as raízes da mandioca [...] a ferver em grandes potes, e quando bem fervidas [...] as moças assentam-se ao pé a mastigarem as raízes, e [...] tornam a pôr a massa mascada nos potes, que então enchem d'água, e misturam muito bem, deixado tudo ferver de novo. Há [...] umas vasilhas especiais, que estão enterradas até o meio [...] Aí despejam tudo e tampam bem; começa a bebida a fermentar e torna-se forte. [...] depois do que, bebem e ficam bêbados. [...] Cada cabana faz sua própria bebida. E quando uma aldeia inteira quer fazer festas, [...] reúnem-se todos primeiro em uma cabana, [...] passam depois para outra [...], e assim por diante até que tenham bebido tudo em todas elas. Quando bebem assentam-se ao redor dos potes [...] Alguns ficam de pé, cantam e dançam [...] O beber dura a noite inteira [...] e, quando ficam bêbados, gritam, tocam trombetas e fazem um barulho formidável. [...] São [...] muito liberais, e o que lhes sobra em comida repartem com outros. (ADES, 1997, pp.146-147)

Staden descreve ainda no capítulo XXIX do livro, Com que cerimônia matam e comem seus inimigos. Como os matam e como os tratam, afirmando que: "Não o fazem por fome, mas por grande ódio e inveja". Toda essa descrição vem a ilustrar não só o ritual antropófago na sua origem, mas também a origem do fenômeno antropofágico de assimilação e recusa, o qual os Modernistas consideravam como sendo a principal característica da identidade da Arte e do povo brasileiro.

Quando trazem para casa os seus inimigos, as mulheres e as crianças os esbofeteiam. Enfeitam-nos depois com penas pardas; [...]; dançam em roda deles, amarrando-os bem, para que não fujam. Dão-lhes uma mulher par os guardar e também ter relações com eles. Se ela concebe, educam a criança até ficar grande; e depois quando melhor thes parece, matam-na e a devoram. Fornecem aos prisioneiros boa comida: tratam assim deles algum tempo, e ao começarem os preparativos, fabricam muitos potes especiais [...]; ajuntam feixes de penas [...]. Trançam também uma corda comprida a que chamam Messurana [muçurana] [...]. Terminados todos os preparativos, marcam o dia do sacrifício. Convidam então selvagens de outras aldeias para aí se reunirem naquela época. Enchem todas as vasilhas de bebidas, conduzem o prisioneiro uma ou duas vezes pela praça e dançam ao redor dele. Reunidos todos os convidados, o chefe da cabana lhes dá boas-vindas [...]. No mesmo dia, pintam e enfeitam o bastão chamado de Iwera Pemme (ibirapema) com que matam o prisioneiro [...], penduram-no em uma cabana desocupada e cantam ao redor dele toda a noite. Do mesmo modo pintam a cara do prisioneiro, e enquanto uma das mulheres está pintando, as outras cantam. E logo que começam a beber, levam o prisioneiro para lá, bebem com ele e com ele se entretêm. Acabando de beber, descansam no dia seguinte; fazem depois uma casinha para o prisioneiro [...]. Ali ele fica durante a noite [...]. De manhã antes de clarear o dia, vão dançar e cantar ao redor do bastão com que o devem matar. Tiram o prisioneiro da casinha e a desmancham [...]; amarram a muçurana ao pescoço e em redor do corpo do prisioneiro, esticando-a para os dois lados. [...] e muitos deles a seguram a corda pelas duas pontas. Deixam-no assim ficar por algum tempo; [...] as mulheres [...] andam em redor ameaçando de devorá-lo. [...] elas estão pintadas e prontas para, quando o prisioneiro estiver reduzido a postas, comerem os quatro primeiros pedaços ao redor das cabanas. [...] Isto pronto, fazem fogo a cerca de dois passos do prisioneiro para que este o veja. Depois vem uma mulher correndo com o ibirapema; $[. .$.$] grita de alegria e passa pelo$ prisioneiro, para que este o veja. Feito isto, um homem toma da clava; dirigi-se para o prisioneiro; pára na sua frente e lhe mostra o cacete para que ele o veja. Enquanto isso, aquele que deve matar o prisioneiro vai com uns 14 ou 15 dos seus e pinta o próprio corpo de pardo, com cinzas. Volta então com os seus companheiros para o lugar onde está o prisioneiro, e aquele que tinha ficado em frente deste lhe entrega a maça. Surge agora o principal das cabanas; toma a clava e enfia por entre as pernas daquele que deve desfechar o golpe mortal. Isso é por eles considerada uma grande honra. [...] Então desfecha-lhe o matador um golpe na nuca, os miolos saltam e logo as mulheres tomam o corpo, puxando-o para o fogo; esfolam-no até ficar bem alvos [...]. Uma vez esfolado, um homem o toma e lhe corta as pernas, acima dos joelhos, e também os braços. Vêm então as mulheres; pegam nos quatro pedaços e correm ao redor

DAPesquisa, Florianópolis, v.2, n.4, p. 234-240, 2007. 
das cabanas, fazendo um grande vozeirio. Depois abrem-lhe as costas, que separam do lado da frente, e repartem entre si; [...] as mulheres [...] Comem os intestinos e também a carne da cabeça; os miolos, a língua e o mais que houver são para as crianças. Tudo acabado, volta cada qual para sua casa levando o seu quinhão. Aquele que foi o matador, ganha mais um nome, e o principal das cabanas risca-lhe o braço com o dente de um animal feroz. Quando sara, fica a marca, e isto é a honra que tem. [...] (ADES, 1997, pp. 159-166)

A marca, deixada como vestígio do ritual antropófago, materializa a transcendência do ritual, e vem a demarcar a honra aos seus, a honra de uma descendência, de uma nacionalidade, de uma nação, o que motiva os Modernistas Brasileiros a identificar e resgatar na Antropofagia uma defesa nacional contra o domínio exterior, capaz de impedir a adesão total a um colonialismo cultural.

Ao longo de quatro séculos, a antropofagia havia sido reprimida e com isso havia se tornado um elemento interditado tanto no discurso "culto" do país, quanto dentro da própria cultura indígena, sendo resgatada no primeiro movimento modernista com voraz veracidade, impulsionada pela busca de uma nacionalidade e por um caráter único de assimilação e recusa, que reconhece na Antropofagia Brasileira a identidade do país, considerando que a característica peculiar brasileira se dá a partir de um caldo cultural constituído de elementos formativos que ainda se colocam na problemática da produção e da criação artística do país no presente. "Havia lá um futuro: escorrem ainda pelos muros do labirinto, e entre raízes, as babas do cauim.” (MARTINS, 2006)

\section{Referências Bibliográficas:}

ADES, Daw. Arte na América Latina. S.P.: Cosac \& Naify, 1997.

ANDRADE, Oswald. Manifesto Antropófago. In: Revista de Antropofagia, Ano 1, No 1, São Paulo, maio de 1928.

ALAMBERT, Francisco. A Semana de 22. São Paulo: Editora Scipione Ltda, 1992.

MARTINS, Marta. Babas no muro do labirinto. Texto apresentado no Colóquio Póscrítica, na Universidade Federal de Santa Catarina, Florianópolis, Dez/2006.

STADEN, Hans (1557). Viagem ao Brasil. Coleção a Obra-Prima de cada autor. SP. Martins Fontes. 2006. 